\title{
A young man with extensor eruptive skin lesions
}

\author{
Satishkumar Balasubramanian, Shriraam Mahadevan, Krishna Seshadri
}

Department of Endocrinology, Diabetes and Metabolism, Sri Ramachandra University, Chennai, Tamil Nadu, India

\section{Correspondence to}

Dr Krishna Seshadri,

krishnagseshadri@gmail.com

Accepted 19 November 2015

\section{DESCRIPTION}

An obese 35-year-old man with a history of heavy alcohol consumption presented with non-pruritic papular skin eruptions of 3 months duration (figure 1). He was recently diagnosed to have type 2 diabetes, which was not well controlled (glycated haemoglobin, HbA1c 10.5\%). Systemic examination was normal except for hepatomegaly. Serum biochemistry showed severe hypertriglyceridaemia $(1550 \mathrm{mg} / \mathrm{dL}) \quad(\mathrm{N}:<150 \mathrm{mg} / \mathrm{dL})$. Other laboratory investigations included mild elevation of transaminases and normal amylase, lipase, renal and thyroid functions. Ultrasound of the abdomen revealed significant hepatic steatosis. This clinical picture was consistent with the diagnosis of eruptive xanthoma due to severe hypertriglyceridaemia secondary to uncontrolled diabetes mellitus and alcohol intake. The patient was counselled on alcohol cessation and strict dietary measures, and placed on insulin therapy and metformin. In addition, fenofibrate was added to prevent pancreatitis. At 3 months of follow-up, his skin lesions had disappeared (figure 2), glycaemic control was better (HbA1c 8.1\%) and lipid profile showed significant reduction in triglyceride levels $(220 \mathrm{mg} / \mathrm{dL})(\mathrm{N}:<150 \mathrm{mg} / \mathrm{dL})$.

Eruptive xanthomas are round yellowish waxy skin lesions usually appearing in the back and extensor surface of the extremities, and are caused by severe hypertriglyceridaemia. ${ }^{1}$ The latter may be due to uncontrolled diabetes mellitus, alcoholism, morbid obesity with significant insulin resistance and uncontrolled hypothyroidism. The main risk of

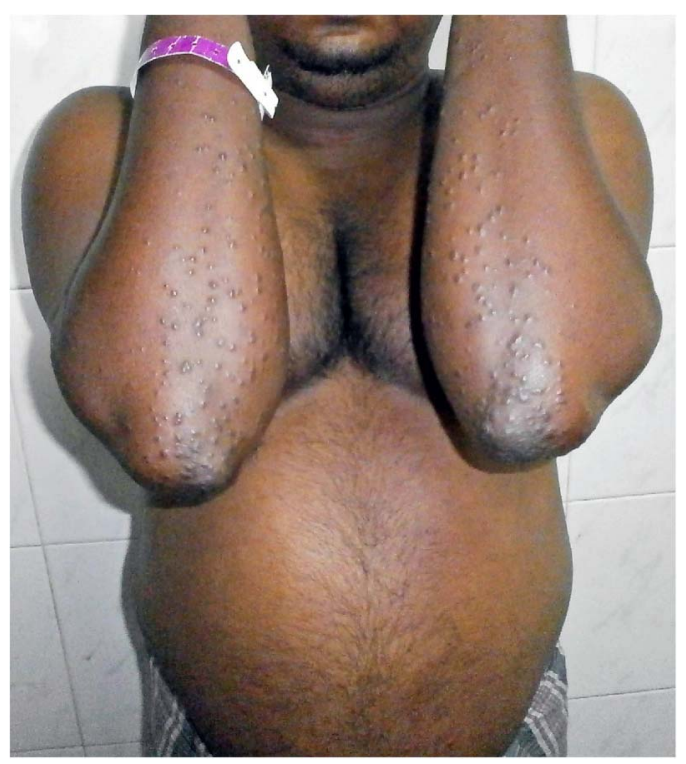

Figure 1 Papular waxy lesions of eruptive xanthoma seen in the extensor surface of both upper limbs. Also visible is significant abdominal obesity.

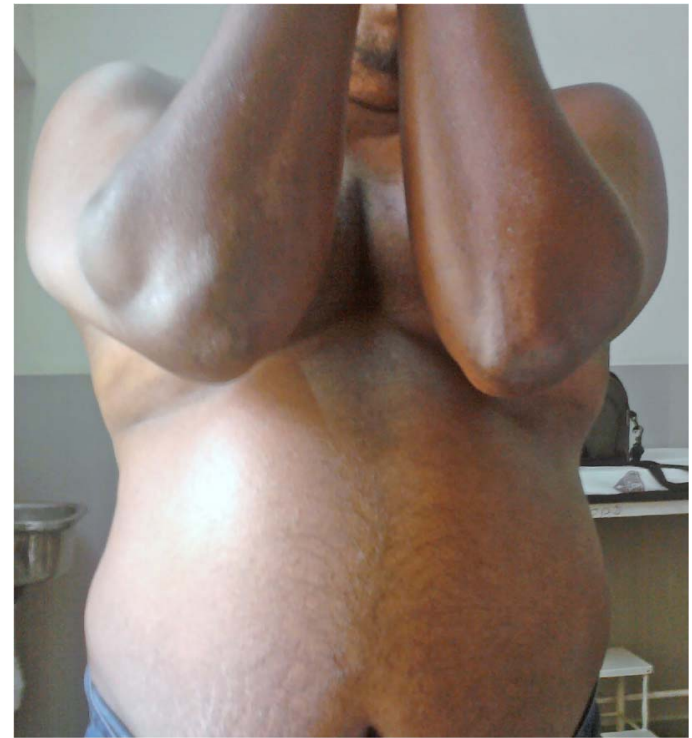

Figure 2 After 3 months of good glycaemic control and alcohol abstinence, the xanthomas disappeared.

severe hypertriglyceridaemia is pancreatitis, and may be prevented with control of secondary causes and the judicious use of fibric acid derivatives. ${ }^{2}$

\section{Learning points}

- The major risk of severe hypertriglyceridaemia is pancreatitis.

- Secondary causes of hypertriglyceridaemia include alcohol overuse, uncontrolled diabetes mellitus, uncontrolled hypothyroidism, nephrotic syndrome and, occasionally, oral oestrogen preparations.

- The secondary causes listed above should be carefully evaluated for and controlled well in every patient with severe hypertriglyceridaemia before beginning fibric acid or other pharmacological therapies.

Competing interests None declared.

Patient consent Obtained.

Provenance and peer review Not commissioned; externally peer reviewed.

\section{REFERENCES}

1 Nayak KR, Daly RG. Eruptive xanthomas associated with hypertriglyceridemia and new-onset diabetes mellitus. $N$ Engl J Med 2004;350:1253.

2 Ladizinski $B$, Lee $\mathrm{KC}$. Eruptive xanthomas in a patient with severe hypertriglyceridemia and type 2 diabetes. CMAJ 2013;185:1600. 
Copyright 2015 BMJ Publishing Group. All rights reserved. For permission to reuse any of this content visit http://group.bmj.com/group/rights-licensing/permissions.

BMJ Case Report Fellows may re-use this article for personal use and teaching without any further permission.

Become a Fellow of BMJ Case Reports today and you can:

- Submit as many cases as you like

- Enjoy fast sympathetic peer review and rapid publication of accepted articles

- Access all the published articles

- Re-use any of the published material for personal use and teaching without further permission

For information on Institutional Fellowships contact consortiasales@bmjgroup.com

Visit casereports.bmj.com for more articles like this and to become a Fellow 